\title{
Indicators for identification of urban flooding vulnerability
}

\author{
B. Barroca ${ }^{1, *}$, P. Bernardara ${ }^{1,2}$, J. M. Mouchel $^{1}$, and G. Hubert ${ }^{3}$ \\ ${ }^{1}$ CEREVE - Ecole Nationale des Ponts et Chaussées, France \\ ${ }^{2}$ HHLY - Cemagref, Lyon, France \\ ${ }^{3}$ MRTE - University Cergy-Pontoise, Cergy-Pontoise, France \\ *now at: LGUEH - University Marne-la-Vallée, Champs sur Marne, France
}

Received: 14 July 2005 - Revised: 1 March 2006 - Accepted: 3 March 2006 - Published: 23 June 2006

\begin{abstract}
In the last 5 years in France, we have observed that each new flood event exposes the weaknesses of the existing prevention system as well as the local weakness. Such events raise questions about the relevance and the effectiveness of the means of prevention. But these events also reveal resistance of the exposed territories, which shows that effective and adequate local strategies exist. There are various methods to evaluate the weakness, or vulnerability of an area, but since the last ten years the qualitative approach of vulnerability in flood risks became more important. Nevertheless, local authorities are often unable to evaluate the vulnerabilities of their territory. Local decision makers request tools for a better assessment of flooding vulnerability. Thus, many approaches of the weakness and the resistance of frequently flooded territories were developed on various scales. These approaches are often partial and contextual. There is a clear need for a support of the evaluation of vulnerability. However, there are obvious synergies between these different approaches, with regard to data retrieval and the establishment of adequate information systems taking into account the vulnerability of a specific territory.
\end{abstract}

The paper develops a methodology aimed to organize into a software tool the choice of vulnerability indicators and the integration of the point of view of various stakeholders (economists, town planners, experts, political leaders, etc). This challenge is based on three simple statements: break down of the problems of vulnerability into homogeneous subsets and manage them; articulation of these subsets in a graphical interface allowing the presentation of interactions between the indicators of vulnerability and compare the opposed visions of vulnerability.

The interface of the tool integrates various vulnerability indicators, which are organised in several categories, in order to allow a flexible and efficient vulnerability analysis.

Correspondence to: B. Barroca

(barroca@cereve.enpc.fr)

\section{Introduction}

Risk consists of hazard and vulnerability. We can define "hazard" like "a threatening event, or the probability of occurrence of a potentially damaging phenomenon within a given time period and area" (European Center of Technological Safety, 2000). When a hazardous event ("hazard") occurs, the damage depends on the elements at risk. "Element at risk" is "the population, buildings and civil engineering works, economic activities, public services and infrastructure, etc. exposed to hazards" (European Center of Technological Safety, 2000).

Vulnerability is a complex notion defining for each hazard the resulting impacts. In general "vulnerability" is the "susceptibility to degradation or damage from adverse factors or influences" (Regional Vulnerability Assessment of United States Environmental Protection Agency).

The public, the government, planners and insurance companies (Wisner et al., 2004) are more and more concerned by flooding disasters and increasing damages (human and economic).

In France for example, the magnitude and frequency of floods is increasing. Easily flooded spaces are often very demanded for urban development. "80\% of the construction permits in flood zones were delivered during the last 40 years. It is estimated that two million people live today in these zones" (Mathot and Mariani, 1994). Furthermore, attractive areas for the population (Fig. 2) correspond to territories touched by floods (Fig. 1). The concentration of the population in the flooded zones will increase their vulnerability and consequently the risk.

Thus it can be seen that flooding risk is a combination of the factors that determine the vulnerability and the exposure potential for people. The revalorization of vulnerability studies is an essential basis for goal definition in land risk management. In the result of the last public survey, it seems that the lack of knowledge of the local vulnerabilities, explains the bad territorial management choices and sometimes

Published by Copernicus GmbH on behalf of the European Geosciences Union. 


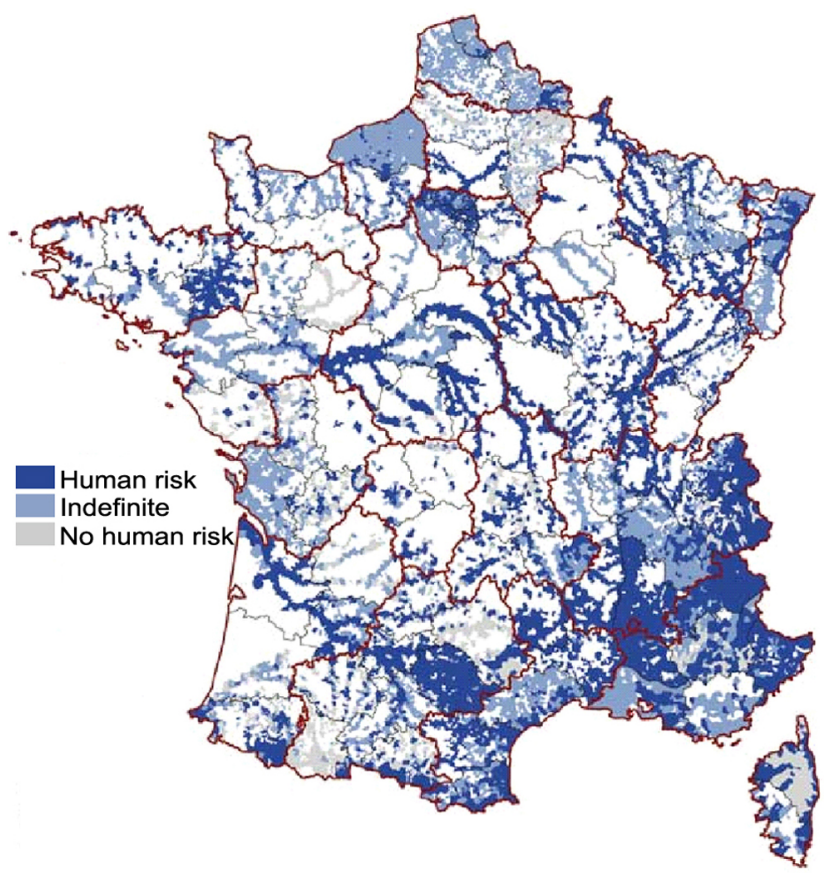

Fig. 1. French flooding risk (http://www.prim.net, 2004).

"dangerous" new constructions projects (Huet et al., 2003). Integration of flood risk in territorial management needs a better knowledge of the vulnerability. The recent law of 30 July 2003 related to risk prevention includes the reduction of the vulnerability of properties and people through the revision of urban planning, type of urbanization and the lawful cartography. The reduction of risk rises not only from hazard analysis but also from the land vulnerability analysis (Pottier, 2003).

In the context of floodplain and flood management planning, and particularly in sustainable integrated approaches, the need of knowledge on vulnerability is also very important (Prater and Lindell, 2000). Under strong local pressure, many communities start prevention strategies without a real knowledge of the territory vulnerability. A better knowledge of the risks (and not only of the hazard) makes it possible to propose alternative solutions to structural approaches. Unfortunately, decision makers and citizens prefer often structural approaches for their "visibility", even if they show limits. Hydrological systems and their problems are a highly discussed topic. Local decision makers are using existing methodologies in order to carry out the hazard analysis. On the other hand, knowledge of the social system and its vulnerabilities is still very weakly developed, even though it is a key element of the social response to a flood and of the urban dynamics (Hall et al., 2003; Huet et al., 2003).

Thus, in spite of the various regulations the institutional standard is not always applied. This is perceived as a lack of willingness on the decision level (Pottier, 2000; Shrubsole et al., 1997). Vulnerability becomes a statutory value if

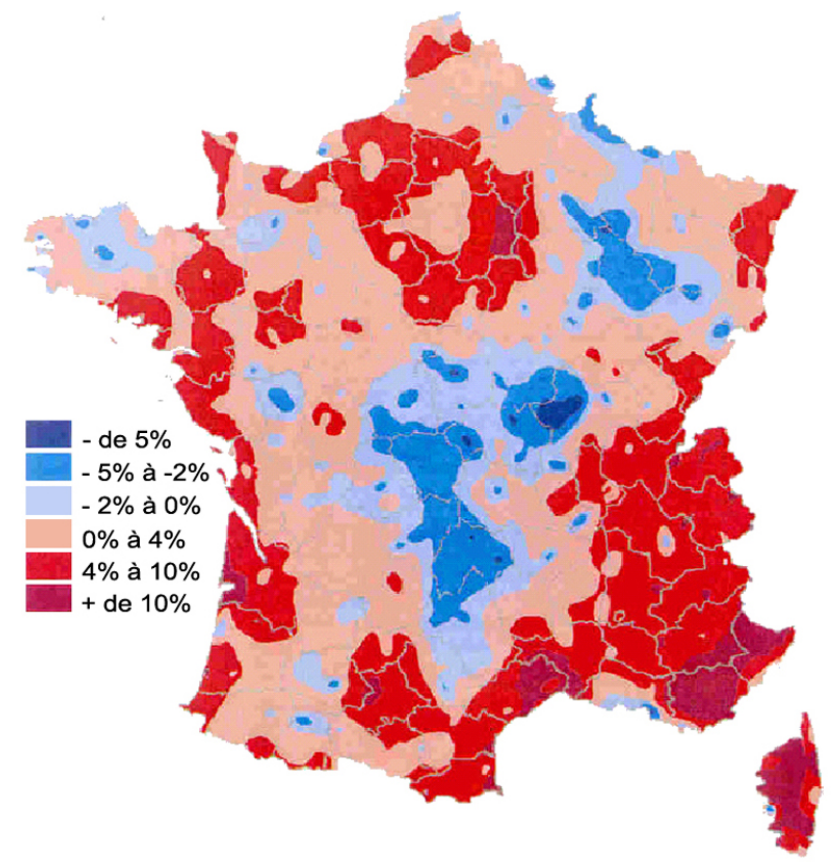

Fig. 2. Prediction of French population variation between 20002020 (Le Bras, 2002).

it is based on public participation and not only a subject of discussion after flooding events (Moris-Oswald and Sinclair, 2005). For this reason the focus should be put on the need of the participation all the stakeholders on the vulnerability understanding and modelling.

Moreover, in future, vulnerability studies should focus more on the local level according to Comfort et al., "Investment in risk reduction is likely to be most efficient and effective when directed toward improving local capacity to act in coordinated ways to achieve this community-wide goal. The link between policy and practice in disaster mitigation needs to be established at the local level" (Comfort et al., 1999).

The interesting point about vulnerability is that it can be examined at different levels and scales for different issues. It can be used to look at a single issue such as a building, or to assess a complex entity such as a town.

This article is focused on the identification methodology of flooding vulnerability. We thus present the procedure to build a set of integrated indicators and to organise them in useful categories. The interface helps the end users to select the pertinent indicators for their case studies, facilitating the participation of the stakeholders. The final aim is to provide the stakeholders with a tool for the vulnerability analysis, flexible in order to be used at local scale and on different nature case study and able to gather different visions of vulnerability. The tools will be able to give information about the various aspects of vulnerability, to demonstrate the relationships between indicators (enhancing or decreasing vulnerability), to illustrate the development of indicators and to helping the 
end-user in the development of its personal set of indicators, where all aspects of vulnerability should be covered (or not covered for some specified purpose).

The paper is structured in 6 sections with an introduction in Sect. 1. Section 2 shows the scientific and operational context of the vulnerability analysis and a brief review of the currently used methodology.

Section 3 presents the tool and the methodological aspects for the identification of vulnerability indicators. It follows a description of their use, their organisation in trees and the graphical representation.

The Sect. 4 discusses the tool's potentials and limits, while Sect. 5 suggest some possible potential development. Section 6 is the concluding part of the paper where some comments on the expected benefit and future perspectives are done.

\section{The context: growing interest in evaluation of vulner- ability}

\subsection{Vulnerability: an unclear definition}

The word vulnerability has been used by the geographs of the Chicago University since the first half of XX century, referring to the Mississippi valley (AFPCN, 2005). In practice there are many different definitions of vulnerability. That is explained by the specific aspects of the vulnerability which depend on the type of study, on the results required (damage evaluation or urban planning project), on the kind of flood hazard (flash-flood or slow-flood) on the spatial and temporal scale of study, on the specificity of the study area, on the temporality (prevention, crisis, post crisis). Some definitions focus on the protection of individuals, others on the maintenance of economic activities or the protection of the environment. Finally, vulnerability definition is also linked to the particular system functions analysed (Parent et al., 1999).

To give some examples of the complexity of this definition, one can show that it includes different time scales and accentuates time as a factor regarding succeeding disasters, in fact, Ben Wisner et al. show that more vulnerable zones have longer recovery phases (Wisner et al., 2004). Again, other authors complete the definition with "the weakness of a socio-economic system as a whole confronted with risk" (Hubert and Ledoux, 1999) or as "propensity of a society exposed to suffer more or less serious damage during occurrence of the hazard" (D'ercole and Pigeon, 1999). In the Vulnerability and Capacity Assessment, a risk analysis toolbox, it is stated that "Vulnerabilities must always be assessed in relation to a specified threat (or hazard): which groups of people are vulnerable to what and why." (IFRC, 1996). Some authors give interesting synthesis of the vulnerability definitions (AFPCN, 2005; Cutter, 2003).These definitions have been grouped using the concept of quantitative versus qualitative definitions (D'ercole, 1994), or analytic versus synthetic definitions (Dauphiné, 2001).

Trying to take into account all these approaches, we resume the complexity of vulnerability definition at least on three levels:

The first complexity of vulnerability concerns the event itself: Hazard is complex and can take various forms. It cannot be described in a simple way, as the various scales which can be used, do not refer to the same damages, and hence do not have an impact of same intensity. In the case of flooding, water level, immersion velocity, flow, water quality and frequency of events are example criteria used to evaluate the hazard. This is called external complexity.

The second complexity of vulnerability concerns the various types of functions of the "element at risk" which can be affected by the hazard. Effects on shelter constructions, transportation, industrial activity, health services do not have the same impact in terms of vulnerability. The time scales of the effects may be very different. Short term effects may cause human casualties or direct costs to economic activities, whereas on longer time scales costs for maintenance will be considered more important. This is called the "first inherent complexity" of vulnerability.

The third complexity aspect of vulnerability is connected to the intelligence of element at risk and relations between the object at risk. Being aware of the risk, in all its components, individuals or societies are able to react. They may organise rescue systems, modify urban development plans, or change building techniques. This is called the "second inherent complexity", which is even more complex to assess.

\subsection{A brief literature review of vulnerability evaluation}

Historically, the evaluation of vulnerability was conceived to support technical and financial choices for protection against floods (Blong, 2003; D'ercole, 1994; Leone et al., 1996; Parker et al., 1987; Penning-Rowsell et al., 1992). So, the first vulnerability analysis linked to flood hazard was done in the USA and Great Britain since the seventies (Flax et al., 2002; Foster, 1976; Penning-Rowsell and Chatterton, 1977). Various research teams worked on socio-economical analyses: Flood Hazard Research Centre (Middelsex University), Centre for Social an Economic Research on the Global Environment (University of East Anglia) and Risk and Policy Analysis, among others.

Today, risk management is an object of social debate, which must lead to explicit collective choices (Lefevre, 1995; STRATEGIS, 2002). The evaluation of the socio-economic impacts of floods should not continue to be locked up in a cost-benefit logic (Dauphiné, 2001; DEFRA, 2002; Gendreau, 1999). These methods must include a quantitative and qualitative analysis (Flax et al., 2002; ODPM, 2001). One of them is the toolbox Vulnerability and Capacity Assessment (IFRC, 1996), identifying potential threats, vulnerabilities, assessing capacities and strengths. 
The purpose of this type of evaluation is to estimate the space distribution of element at risk as well as possible, their importance (network, Felts, 2002; strategic crisis-element, Godin et al., 2004), their vulnerability. A risk calculation can show the possibilities for vulnerability reduction (local territorial strategies, vulnerability assessment of buildings, temporary relocation and reception capacity) (IFRC, 1996; Ledoux, 1995). As above mentioned various methods of quantitative risk analyses are available for flood risks and also for landslides (Bell and Glade, 2004).

Some documents identify the building vulnerability (volcano vulnerability, Pomonis et al., 1999; tephra fall, Spence et al., 2005; flood vulnerability, Kelman and Spencer, 2003; Valencia et al., 2004; seismic vulnerability, Mebarki and Valencia, 2004). Some identify as well elements likely to affect human vulnerability, and classify the building stock (Spence et al., 2004). Others determine respective levels of vulnerability of people and buildings (for landslide the results are given in Glade (2003), for risk due to tunnelling and excavation in Zihri (2004). Others according to Wisner et al. (2004) presents a conceptual framework for addressing temporal variation in natural risk (Hufschmidt et al., 2005). Various recent works suggest the use of a unique and aggregated value or "index" to quantify the damages. This is actually the case of the "Damage Index 1999" and the "Central Damage Values" which uses an average rate of damage (NHRC, 1999). This methods has been widely used in Australia by the Insurance Foundation. The Environmental Vulnerability Index (SOPAC and UNEP, 2005) belongs to a new generation of tools. It supports the assessment and gives advice to decision-makers. Furthermore it intends to combine measures of economic and social vulnerability. Again, some studies described the most important factors and proposed methods for an index of economic vulnerabilities for different countries (Briguglio, 1995). Another method (not specific to natural hazard) presents the social and economic adaptive capacity. This is a point of departure for the construction of indices of vulnerability (Yohe and Tol, 2002).

This brief review shows, that a set of tools and procedures exist for the quantification of the vulnerability and for the identification of areas at risk. At the same time no method exists to select vulnerability factors specifically for a particular case study.

\section{A new support tool for vulnerability analysis}

The proposed support tool includes a set of indicators, referring to widely shared functions of urban systems that allow the final users to simplify them as much as possible while demonstrating their implementation in relevant case studies. A comprehensive list of vulnerability indicators would be irrelevant for a given situation (e.g. vulnerability indicators referring to non-existing types of land-use). Thus, the methodology to evaluate them is strongly context-dependent (e.g. characteristics of housing used to evaluate vulnerability, depend on local architectural traditions). The tool is used before the vulnerability evaluation, as it helps to draft a preliminary analysis presenting the main indicators to be studied.

\subsection{Methodological aspects for indicator identification}

The method for identification of indicators is result of a literature review, which was based on complementary levels: the local project bibliography, the scientific bibliography, and the research project bibliography. We synthesize and identify the expertise coming from:

(i) Literature available on local level: it contains the whole of the expert reports, notes, studies, diagnostic etc. related to a specific context (Ayral, 2002).

(ii) The scientific literature: it includes internationally and nationally reviewed articles in order to introduce methodological elements for a study.

(iii) The research project reports: they include contributions from analysis coming from other areas and other programs not being the subject of scientific publication (European framework programs, national programs, regional programs)

(iv) Moreover we will take into account case studies conducted within the framework of this study in order to improve the bibliographical database (Lefort, 2003, 2004; Pottier et al., 2004). The indicators must represent a consensus. They have to be measurable on a local scale according to final vulnerability characterization objectives (in agreement with national law). They have to be oriented within the logistic and technical limits related to the catchment scale. Data sources are identified, and an updating of the database is needed with in regular intervals. For the indicators which require specific data, the methodologies attached to the collected data must be known.

\subsection{Organization and use of the indicators}

The indicators are structured in a tree configuration. Primarily they are organised in five principal modules, which include seven main groups. More subdivisions can be added. The seven groups (Fig. 3) contain each a list of indicators related to the studied field.

The tree structure shows the heritage concept (module/group/indicator) as (branch/sub-branch/leaf) but not the complex interactions between the indicators. Indeed the user can create his personal list of indicators extracting them from various groups; in fact he decides which indicators need to be considered in his specific case. Thus any type of relation between indicators must be enlightened. In order to facilitate browsing, several sets of key-words have been proposed. 


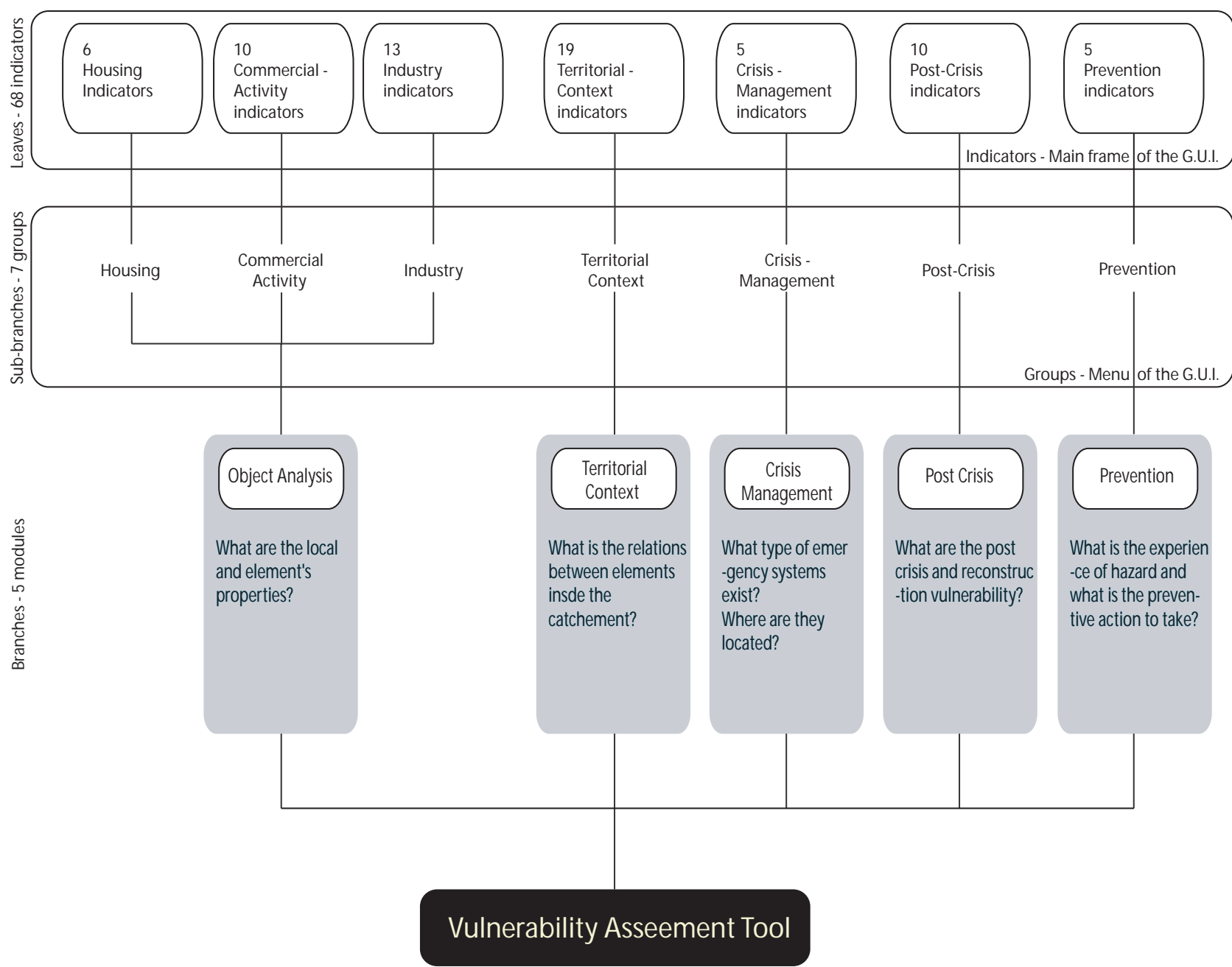

Fig. 3. The seven groups of the vulnerability tool.

Each indicator has one or more associated key-words, enabling browsing to neighbour indicators. For example, a user can extract the vulnerability indicators related to land management key-word in the same way another user might be interested in his specific case study indicators (which can be the vulnerability of a specific flood). This is a list key-words types:

(i) Sector type key-words are connected to the group of actors involved in the indicator: economy and employment, construction and urban planning, assistance and safety, sanitary and social, ecology and environment, physical and psychological health (the individuals) etc...

(ii) Data type key-words regard the type of data or databases which could be used to assess the indicators.

(iii) Aspects type key-words refer to wide field of thoughts of values the indicator can be related to: moral, economic, aesthetic etc... (Geldof Govert, 1994) (iv) Examples type key-words enable browsing through a series of case studies with numerous relevant indicators, providing interesting references.

On the software side, the tool consists of a set of HTML/PHP files, and can be viewed on any browser. The starting page can be called up with a specified key-word. From a design point of view, the Graphic User Interface (GUI) consists of two windows, (Fig. 4). On the left the selected indicator page is shown, including the indicator descriptions and associated key-word for browsing. On the right, all indicators are listed. Instead of the whole list of indicators the users can choice to view only the indicators associated to a given key-word: clicking on one of the key-word inside the indicator page on the left, highlights the corresponding indicators in the list on the right. And finally, when the interesting indicators are chosen, clicking on a specific indicator name on the right opens the window presenting it. 
33) Mozilla Firefox

Eichier Edition Affichage Aller à Marque-pages Ouțils ?
Démarrage $\mathrm{Q}$ Dernières nouvelles

\section{Usage (Personal property, movables)}

$\begin{array}{ll}\text { Group } & \text { Housing } \\ \text { Sector } & \text { Construction and Urban Planning } \\ \text { Aspect } & \text { Moral } \\ \text { Data } & \text { Insurance } \\ \text { Data } & \text { Tvpe of Construction } \\ \text { Example Braubach and Kraiburg } \\ \text { Example Brittany }\end{array}$

Back to top page

Relevance

Adapting usages lowers damages to movable, and lessens psychological traumas

\section{Description}

Without any specific prevention measure, flood damages in residential areas are similar for movable goods and buildings. Damages to movable goods include damages to furniture (40\%) and other housing equipment (40\%) while the remaining $20 \%$ include doors and big electrical equipment.

Adapting usages:

Damages can be rediced by suppressing some usages of rooms situated below the flood level. It was estimated that adapting room usages could reduce the costs by 30 to $40 \%$. (Egli T., 2002)

\section{Example : Braubach and Kraiburg}

In Kraiburg, damages to furniture, heating devices and other goods is $40 \%$ of the total damage.

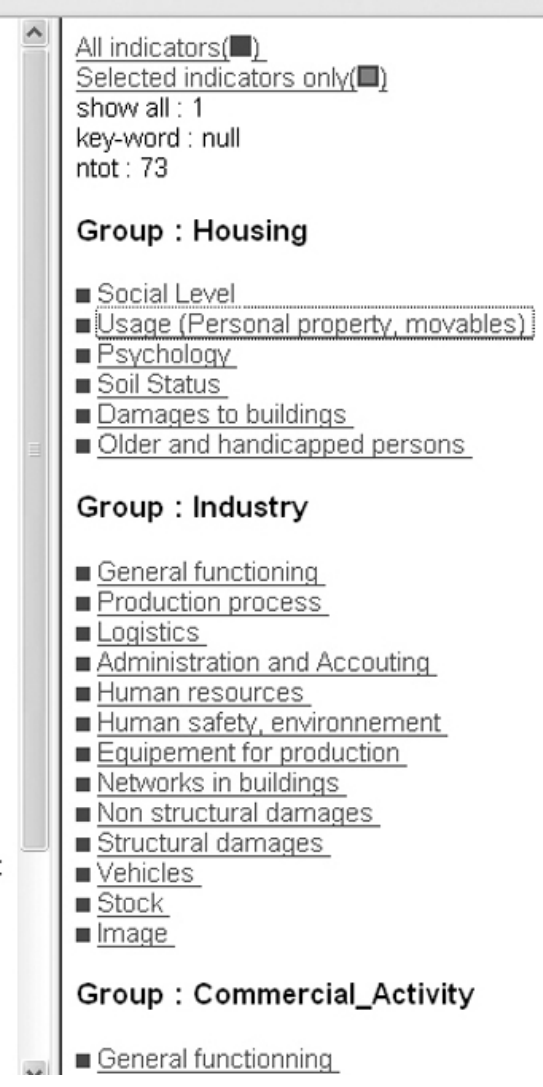

Fig. 4. Screen shot of the vulnerability tool (right: menu list of indicators, left: indicator description).

French and English versions are available on the web site http://www.daywater.h2o.net/.

\section{Discussion}

In the previous context analysis we pointed out that we face an increasing need for more careful vulnerability analysis but we observe also a lack of customized instruments. We also highlight that the potential users are multiple, including all urban water manager. But, to reach the goal of broad operational use, verification is needed. The tool is presently been testing on different frameworks. It is used for vulnerability analysis of some case study during the courses of flood risk and GIS at the Marne La Vallée University, Paris. Operational experiments carried out by first-users are currently in progress. Comments collected during first-testing are mentioned below:

(i) The idea of building a wide indicator set is appreciated by the tester. The users can easily work on the pre-crisis and post-crisis management. The decision-makers and the stake-holders are encouraged and supported in the decision-making process. (ii) The comparison of the indicators within the tools was appreciated in particular for his flexibility. There was positive feedback of listing a large number of indicators, where the users can select the indicators for their case study.

(iii) Some tester suggested to increase the number of indicators in order to increase the range of users. So that the tool could be used for the diagnosis of vulnerability at the scale of each "element at risk". These methods already exist and will be mentioned in the tool (GC and MEDD, 2004; Langumier, 2001); presently we focus on urban scale.

\section{Perspectives}

In order to allow the stakeholders to increase their participation to the vulnerability analysis, some possible future development of the tool has been pointed out. One perspective is to 
consider how to improve the use of the results. What can be proposed for a post treatment to advance towards decisionmaking support? Various methods of decision-making support do exist. Would it be useful to couple these methods with the tool? Moreover, acquisition, management and updating of geographical information remain difficult, but they are essential for the evaluation of indicators. In the future development public participation and GIS should be coupled, see "Public Participation Geographic Information Systems" (PPGIS) (Jankowski and Nyerges, 2001). These devices use geographic information or geographic technologies, developed partly by and for the public, with an aim of supporting the participation of the public in the local processes of territorial management (data, cartography, space analysis, territorial decision etc.) (Edwards and Ligaza, 2004). Public participation GIS could be seen as the most popular and current solution.

\section{Conclusion}

Knowledge of the process of vulnerability identification represents a very important contribution to decrease and control the land damage caused by natural hazard. The purpose of the vulnerability study is to limit weakness and integrate flood risk into urban development. The proposed vulnerability analysis tool creates an integrated vision of the risk for its users. The project is shown to gather various visions of vulnerability and show as well that the analysis of risk must not be disconnected from possible interactions with territorial identity. The tool is also shown to be simple and flexible, adapting itself to different case study and different kind of users. It is also free and no particular technical knowledge is required for its use. It then presents wide potential application, since the potential users are all urban water managers, who often don't have yet the instruments to carry out a deepened vulnerability analysis and who may not have a particular background in vulnerability issue. Thus we expect to increase and help the participation of the stakeholders to the vulnerability assessment process. Some future works could improve the performances of the tool, an interesting perspective being the coupling, into the same system of indicators coming from various spatial scales, or the link with GIS software for the geographical visualization of the information.

Acknowledgements. The authors also thankful to T. Glade, K. Hollenstein and I. Kelman who provided constructive comments.

The results presented in this publication have been obtained within the framework of the EC funded research project "DayWater": "Adaptive Decision Support System for Stormwater Pollution Control", contract no EVK1-CT-2002-00111, co-ordinated by Cereve at ENPC (F) and including Tauw BV (Tauw) (NL), Department of Water Environment Transport at Chalmers University of Technology (Chalmers) (SE), Environment and Resources DTU at Technical University of Denmark (DTU) (DK), Urban Pollution Research Centre at Middlesex University (MU) (UK), Department of Wa- ter Resources Hydraulic and Maritime Works at National Technical University of Athens (NTUA) (GR), DHI Hydroinform, a.s. (DHI HIF) (CZ), Ingenieurgesellschaft Prof. Dr. Sieker GmbH (IPS) (D), Water Pollution Unit at Laboratoire Central des Ponts et Chaussées (LCPC) (F) and Division of Sanitary Engineering at Luleå University of Technology (LTU) (SE).

This project is organised within the "Energy, Environment and Sustainable Development" Programme in the 5th Framework Programme for "Science Research and Technological Development" of the European Commission and is part of the CityNet Cluster, the network of European research projects on integrated urban water management.

Edited by: T. Glade

Reviewed by: K. Hollenstein and I. Kelman

\section{References}

AFPCN: Risques et vulnérabilité, Ecole nationale des Arts et Métiers, Paris, 2005.

Ayral, P. A.: Terminologie en science du risque: Recueil de définitions, 2002.

Bell, R. and Glade, T.: Quantitative risk analysis for landslides - Examples from Býldudalur, NW-Iceland, Nat. Hazards Earth Syst. Sci., 4, 117-131. 2004.

Blong, R.: A review of damage intensity scale, Nat. Hazards Earth Syst. Sci., 29, 57-76. 2003.

Briguglio, L.: Small island developing states and their economic vulnerabilities, World Development, 23(9), 1615-1632. 1995.

Comfort, L., Wisner, B., Cutter, S., Pulwarty, R., Hewitt, K., OliverSmith, A., Wiener, J., Fordham, M., Peacock, W., and Krimgold, F.: Reframing disaster policy: the global evolution of vulnerable communities, Global Environmental Change Part B: Environmental Hazards, 1(1), 39-44. 1999.

Cutter, S. L.: The Science of Vulnerability and the Vulnerability of Science, Annals of the Association of American Geographers, 93(1), 1-12, 2003.

Dauphiné, A.: Risques et catastrophes: Observer,spatialiser, comprendre, gérer, Collection U. Armand Colin, 283, 2001.

DEFRA: Departement For Environment, Food \& Rural Affair - Scheme Prioritisation System, Flood management division,, 2002.

D'ercole, R.: Les vulnérabilités des sociétés et des espaces urbanisés: concepts, typologie, modes d'analyse, Revue de Géographie Alpine, tome LXXXII no. 4, 87-96. 1994.

D'ercole, R. and Pigeon, P.: L'expertise internationale des risques dits naturels: intérêts géographiques., Annales de géographie, 608, 339-357. 1999.

Edwards, G. and Ligaza, G.: A formal model for structuring local perceptions of environmental space, Cognitive processing, 5, 39. 2004.

Felts, D.: Vulnérabilité des réseaux urbains et gestion de crise, Centre d'Etudes sur les Réseaux, les Transports, l'Urbanisme et les constructions publiques, Lyon et Macon, 2002.

Flax, L. K., Jackson, R. W., and Stein, D. N.: Community Vulnerability Assesment Tool Methodology, Nat. Hazards Review, November 2002, 163-176. 2002. 
Foster, H. D.: Assessing disaster magnitude: a social science approach, Professionnal Geographer, 28(3), 241-247. 1976.

GC and MEDD: Vous pensez etre prêt à faire face à une inondation?, Geosciences Consultants - Ministère de l'Ecologie et du Développement Durable, 2004.

Geldof Govert, D.: Policy analysis and complexity, A new equilibrium approach for integrated water management, International Conférence "Living with water", Amsterdam, 417-428, 1994.

Gendreau, N.: La méthode inondabilité, in: Le coût du risque... L'évaluation des impacts socio-économiques des inondations, edited by: Hubert, G. and Ledoux, B., Presses de l'ENPC, Paris, 123-127, 1999.

Glade, T.: Vulnerability assessment in landslide risk analysis, Die Erde, 134, 121-138. 2003.

Godin, C., Halbecq, X., Le-Bris, A., Mallet, C., and Martin, A.: Identification des enjeux exposés au risque d'inondation sur la Loire Moyenne - Rapport de projet SIG/Carto, Cycle des Ingénieurs de l'Ecole Nationale des Sciences Géographiques, 2004.

Hall, J. W., Meadowcroft, I. C., Sayers, P. B., and Bramley, M. E.: Integrate Flood Risk Management in England and Wales, Nat. Hazards Review, 126-135. 2003.

Hubert, G. and Ledoux, B.: Le coût du risque ... l'évaluation des impacts socio-économiques des inondations, Presses de l'Ecole Nationale des Ponts et Chaussées, Paris, 232, 1999.

Huet, P., Martin, X., Prime, J. L., Foin, P., Laurain, C., and Cannard, P.: Retour d'expérience des crues de septembre 2002 dans les départements du Gard, de l'Hérault, du Vaucluse, des Bouches du Rhône, de l'Ardèche et de la Drôme, Rapport IGE (Inspection Générale de l'Environnement), 2003.

Hufschmidt, G., Crozier, M., and Glade, T.: Evolution of natural risk: research framework and perspectives, Nat. Hazards Earth Syst. Sci., 5, 375-387. 2005.

IFRC: Vulnerability and Capacity Assessment, International Federation of Red Cross and red crescent societies, 1996.

Jankowski, P. and Nyerges, T.: Geographic Information System for group decision making, Taylor and Francis, London, 273, 2001.

Kelman, I. and Spencer, R.: A limit Analysis of Unreinforced Masonry Failing Under Flood Water Pressures, Masonry International, 16(2), 2003.

Langumier, A.: Diagnostic de la vulnérabilité aux inondations des services d'eau: Guide méthodologique, Equipe Pluridisciplinaire Plan Loire Grandeur Nature - Ecodécision, 2001.

Le Bras, H.: Croissance démographique 2000-2020, Aménager la France de 2020, Mettre les territoires en mouvement, La Documentation française, Paris, 41, 2002.

Ledoux, B.: Bilan de la mise en oeuvre des méthodologies d'élaboration des études de vulnérabilité dans le cadre des PER entre 1984 et 1994, Ministère de l'Environnement, DPPR, SDPRM, Paris, 1995.

Lefevre, C.: La recomposition territoriale en question: position d'acteurs, Revue de Géographie de Lyon, 70(2), 1995.

Lefort, E.: Dynamique terrtoriale et vulnérabilités aux inondations: Exemple du val de Saône Mâconnais., Université de Versailles Saint-Quentin-en-Yvelines, 2003.

Lefort, E.: Evaluation des vulnérabilités aux inondations dans le cadre de la gestion opérationnelle des risques et du développement local (application au bassin versant de l'Orge aval), ENPC-ENGREF-UPVM, 2004.
Leone, F., Aste, J. P., and Leroi, E.: L'évaluation de la vulnérabilité aux mouvements de terrain, Revue de géographie alpine, 84(1), 35-46. 1996.

Mathot, P. and Mariani, T.: Rapport de la Commission d'enquête parlementaire sur les causes des inondations et les moyens d'y remédier, Journal Officiel, 1641, 28, 1994.

Mebarki, A. and Valencia, N.: Informal Masonry Structures: Seismic Vulnerability and GIS maps, Masonry International Journal, British Masonry Society, 17(1), 18-25. 2004.

Moris-Oswald, T. and Sinclair, A. J.: Values and floodplain management: Case studies from the Red River Basin, Environ. Hazards, 6, 9-22. 2005.

NHRC: Damage Index 1999, NHQ - Natural Hazards Quarterly, 5(4), 1999.

ODPM: Multi-critéria analysis: a manual, Office of the Deputy Prime Minister, 2001.

Parent, C., Spaccapietra, S., and Zimanyi, E.: Spatio-Temporal Conceptual Models: Data Structures + Space + Time, 7th ACM Symposium on Advances in GIS, Kansas City, 1999.

Parker, D., Green, C., and Thompson, P.: Urban Flood Protection Benefits, a project appraisal guide, Red Manual, Gower technical press, 1987.

Penning-Rowsell, E. and Chatterton, J.: The benefits of flood alleviation - A manual of assessment techniques(Blue Manuals), Gower technical press, 297, 1977.

Penning-Rowsell, E., Chatterton, J., Green, C., and Al, E.: The Economics of Coastal Management, a manual of Benefits Assessment Techniques (Yellow Manual), Gower technical press, 1992.

Pomonis, A., Spencer, R., and Baxter, P. J.: Risk assessment of residential buildings for an eruption of Furnas Volcano, J. Volcanology Geothermal Res., 92(1-2), 107-131, 1999.

Pottier, N.: Risques d'inondation, réglementations et territoires, Hommes et Terres du Nord, 2, 93-101, 2000.

Pottier, N.: La lutte contre les inondations en France: outils et stratégies d'hier à demain., Les risques. collection Géographie, éditions du Temps, 173-204, 2003

Pottier, N., Lefort, E., Vinet, F., and Barroca, B.: L'évaluation des vulnérabilités territoriales pour l'aide à la gestion des inondations par les collectivités locales, Colloque international: "Contraintes environnementales et gouvernance des territoires", Lille, 2004.

Prater, C. S. and Lindell, M. K.: Politics of Hazard Mitigation, Nat. Hazards Review, (1, 2), 73-82, 2000.

Shrubsole, D., Hammond, V. J., Kreutzwiser, R., and Woodley, I.: Assessing Floodplain Regulation in Glen Williams, Ontario, Canada, J. Environ. Manage., 50(3), 301-320. 1997.

SOPAC and UNEP: Building Resilience in SIDS - The Environmental Vulnerability Index (EVI), South Pacific Applied Geoscience Commission and United Nations Environment Programme, 2005.

Spence, R. J. S., Baxter, P. J., and Zuccaro, G.: Building vulnerability and human casualty estimation for a pyroclastic flow: a model and its application to Vesuvius, J. Volcanology Geothermal Res., The Neapolitan Volcanoes: Vesuvius, Campi Flegrei and Ischia, 133(1-4), 321-343, 2004.

Spence, R. J. S., Kelman, I., Baxter, P. J., Zuccaro, G., and Petrazzuoli, S.: Residential building and occupant vulnerability to tephra fall, Nat. Hazards Earth Syst. Sci., 5, 477-494. 2005.

STRATEGIS: Etude de faisabilité d'un observatoire des enjeux et 
de leur vulnérabilité aux inondations - Rapport de phase 2: analyse bibliographique, Ministère de l'environnement, Paris, 2002.

Valencia, N., Mebarki, A., and Salagnac, J. L.: Risques naturels et SIG: Application à la vulnérabilité des ouvrages en maçonnerie, XXII Rencontres Universitaires de Génie Civil, UMLV Champs sur Marne, France, 2004.

Wisner, B., Blaikie, P., Cannon, T., and Davis, I.: At Risk: - Second edition - Natural hazards, people's vulnerability and disasters, Routledge, London, 471, 2004. http://www.prim.net: Receuil national des communes à risques, http://www.prim.net/citoyen/definition_risque_majeur/ dossier_risque_inondation/pageintroduction.htm, 2004.

Yohe, G. and Tol, R. S. J.: Indicators for social and economic coping capacity-moving toward a working definition of adaptive capacity, Global Environmental Change, 12(1), 25-40. 2002.

Zihri, G.: Risques liés aux ouvrages souterrains: constitution d'une échelle de dommages, Institut National Polytechnique de Lorraine, 2004. 